\title{
Från patient till medborgare - Personer med funktionshinder möter ett nytt paradigm
}

\author{
STIG LARSSON
}

\begin{abstract}
Denna artikel är en introduktion till några basala teman inom handikappforskningen. Här redogörs för utvecklingen av handikappbegreppet och hur det àterspeglats inom särskilt den svenska handikappolitiken. Vidare diskuteras frägan om hur stort antalet personer med funktionsnedsättningar är med utgångspunkt från skilda definitioner. Det inklusiva perspektivet, där personer med funktionshinder betraktas som medborgare i gemen, börjar bli en etablerad del av den politiska retoriken men sätter ännu i ringa grad spår $i$ de vetenskapliga ansatserna på handikappområdet.
\end{abstract}

\begin{abstract}
Denna artikel är en introduktion i första hand till forskare inom det socialvetenskapliga fältet, som inte vanligtvis är engagerade inom handikappområdet. Min strävan är att sammanfatta och problematisera några grundläggande frågor inom området. En första är: vad är handikapp? Kring denna finns en omfattande begreppslig diskurs. Den har till en del hämtat sin näring från välfärdspolitiken, där det finns behov av att formulera rekvisit för att precisera vilka

Stig Larsson är professor och föreståndare för HAREC, Centrum för handikapp- och rehabiliteringsforskning vid Lunds universitet, som drivs tillsammans med Malmö Högskola, Sveriges Lantbruksuniversitet i Alnarp samt Högskolan i Kristianstad. Han har själv ett allvarligt funktionshinder genom att knappt ha ledsyn.
\end{abstract}

som kan komma i fråga för vissa förmåner. Stundom har diskussionen om handikappbegreppet präglats av manifesta motsättningar mellan olika inomvetenskapliga discipliner. En annan viktig ingång till handikappbegreppet har varit FN:s deklaration om de mänskliga rättigheterna och de standardregler inom handikappområdet som utformats i dess anda. På det internationella planet har också WHO:s harmoniseringssträvanden, som bl.a. inneburit att nytt klassificeringssystem antagits, varit betydelsefulla.

En andra central fråga är: hur många personer medfunktionsnedsättningar finns det? De statistiska källorna är knutna till skilda definitioner, som kan ge oss kunskap om omfattningen av olika handikapp i befolk- 
ningen. I framställningen avgränsar jag mig i huvudsak till Sverige.

Omfattningen av personer med funktionshinder samvarierar antagligen med det samhälleliga klimatets accepterande av dem som grupp. Det är rimligt att anta att de viktigaste förändringarna sammanhänger med den allmänna välfärdsutvecklingen.

För det tredje försöker jag sammanfatta läget för den svenska handikappforskningen. Bl.a. kommer jag därvid att redogöra för rapporter från två grupper, som arbetat $\mathrm{i}$ anslutning till Forskningsrådet för arbetsliv och socialvetenskap. Jag kommer också att knyta an till den internationella diskursen inom handikappforskningen, som i flera viktiga avseenden överensstämmer med den svenska.

Avslutningsvis kan man fråga sig - vad har sammanlagt hänt inom handikappområdet? I detta avsnitt försöker jag komprimerat väva samman och sammanfatta resonemangen i de tre första avsnitten. Min slutsats är att under de senaste femtio åren har ett nytt synsätt - eller om man så vill paradigm formats som bas för synen på personer med funktionshinder, som dock bara begränsat reflekteras inom forskningen.

\section{Begreppsutveckling i politiken}

Den moderna synen på handikapp har successivt växt fram. Detta synsätt kontrasterar bjärt mot det gamla, bl.a. präglat av institutionstänkande och segregering (Qvarsell, 1991). Några studier om hur det moderna begreppet formats som ett resultat av handikapprörelsens strävanden, olika former av vetenskapliga bidrag, allmän välfärdspolitik eller kravet på internationella harmo- nisering har inte gjorts. Samtliga faktorer är emellertid viktiga vid förståelsen av hur olika perspektiv på funktionshinder gestaltats. I flera viktiga avseenden har Sverige och de andra skandinaviska länderna varit banbrytande inom handikappområdet.

Ett betydelsefullt uppbrott från traditionellt tänkande inom handikappolitiken kom redan i mitten av 60-talet, genom Socialpolitiska kommitténs betänkande (SOU 1964:43). Här formulerades flera principer, som kom att bli viktiga fundament i den moderna handikappolitiken, bl.a. atthänsyn till handikappade måste tas överallt i samhället - i samhällsplaneringen och bostadsbyggandet, i utbildningsväsendet och på arbetsmarknaden, i socialförsäkringen och i kulturlivet. En annan viktig princip som fastslogs av kommittén var att hjälpen till handikappade skulle utformas som rättigheter.

Under 1960-talets jämlikhetssträvanden kom de handikappades egna organisationer att spela en framträdande roll i att lyfta fram personer med funktionshinder i den samhälleliga jämlikhetsdebatten. I Handikappförbundens Centralkommitté (HCK) formulerades det miljörelaterade handikappbegreppet. I dess program från 1972 slås fast: "handikapp är i stor utsträckning en följd av brister i samhället. Därför kan handikapp elimineras. Det gör man genom att förändra samhället.» Med denna ambition kom den svenska handikapprörelsen att gå $i$ bräschen för att $\mathrm{i}$ högre grad lyfta fram handikappfrågorna ur ett samhälleligt perspektiv.

Den första handikapputredningen tillsattes år 1965. I dess slutbetänkande (SOU 1976:20) knyter man an till HCK:s synsätt. 
Som resultat av utredningen kan nämnas avvecklingen av de s.k. vanföreanstalterna, införandet av bostadsanpassningsbidrag, kommunala handikappråd, statsbidrag till färdtjänst, och tillskapandet av Handikappinstitutet. I viktiga avseenden kan man hävda att här lades grunddragen för den moderna handikappolitiken.

Denna kan emellertid inte analyseras isolerad från andra delar av socialpolitiken. Sålunda skedde under 1950-talet ett omfattande reformarbete på socialförsäkringsområdet. Den allmänna sjukförsäkringen infördes och i samband med 1962 års socialförsäkringsreform genomfördes förbättringar för långtidssjuka. Handikappersättning och vårdbidrag till föräldrar med funktionshindrade barn byggdes ut senare.

Inom arbetsmarknadspolitiken påbörjades ett ambitiöst arbete redan innan andra världskrigets slut genom den s.k. Kjellmanska kommittén. Dess arbete fick stor betydelse för etableringen av den s.k. arbetsvården, som vid denna tid användes som ett samlat begrepp för olika arbetsförberedande åtgärder för att öka arbetsförmågan hos personer med funktionshinder. Kommittén lanserade också begreppet "normaliseringsprincip", som stod för att inga säråtgärder skulle vidtas förrän man utan resultat prövat andra reguljära åtgärder inom arbetsmarknadsområdet.

I många andra länder etablerades också omedelbart efter andra världskriget en aktiv politik för att rehabilitera krigsskadade personer. Rehabiliteringsmetodik och utveckling av tekniska hjälpmedel blev viktiga arbetsområden. Dessa insatser påverkade också Sverige. I samband med att den aktiva arbetsmarknadspolitiken fick ett genom- slag under 1960-talet ökades förutsättningarna för den yrkesmässiga rehabiliteringen och stödet till personer med s.k. arbetshandikapp. Senare har Lagen om anställningsskydd (1974:12) och Arbetsmiljölagen (1977:1160) på olika sätt stärkt de handikappades situation på arbetsmarknaden. År 1999 infördes Lagen (1999:132) om förbud mot diskriminering $i$ arbetslivet av personer med funktionshinder. Här markeras att personer med funktionshinder har rätt till arbete på samma villkor som andra.

På utbildningsområdet kom begreppen normalisering och integrering att blicentrala mål. Redan 1962 fick kommunerna skyldighet att sörja för undervisning för alla barn inom kommunen med undantag för särskolan, som inte blev en kommunal angelägenhet förrän 1992. Integrationsutredningen, som tillsattes 1978, kom att få stor betydelse för utformningen av dagens stöd till elever med funktionshinder och betonade att integrationspolitiken inom utbildningsområdet inte får stanna vid skolplacering, utan måste ses i ett sammanhang där både tillrättaläggande av miljön och särskilda åtgärder är nödvändiga.

Den senaste stora handikappreformen kom genom Lagen om stöd och service till vissa funktionshindrade (LSS) och Lagen om assistansersättning(LASS)vilka träddeikraft 1994. Ledande handikappolitiska debattörer menar att dessa lagar markerar ett avgörande steg på funktionshindrades långa väg från beroende till oberoende. Det mest konkreta uttrycket för denna reform är rätten till personlig assistens för de personer som har omfattande funktionsnedsättningar (det förs dock en debatt om vilken personkrets som skall avses). För att ha rätt till personlig

Stig Larsson: Från patient till medborgare 
assistens och statlig assistansersättning, som är en del av socialförsäkringssystemet, krävs att man har ett dokumenterat behov av personlig assistans med minst 24 timmar per vecka och är under 65 år. Assistensreformen kan sägas vara ett uttryck för att ge personer med funktionshinder möjlighet att i sitt vardagsliv inte befinna sig i ett kontinuerligt beroende av sjukvårdens eller socialtjänstens vård- eller omsorgspersonal. Målsättningen är att frigöra personer med funktionshinder från patient-och klientrollen och ge dem möjlighet att bli vanliga medborgare (Ekensteen, 1996).

\section{Begreppets internationalisering}

Stor principiell vikt för den svenska handikappolitiken har Handlingsprogrammet $i$ handikappfrågor (SOU 1982:46) haft. Det sammanfattade i viktiga avseenden den ideologiska utvecklingen som skedde under 1960- och 1970-talet. Det togs fram i anslutning till FN:s internationella handikappår. FN:s generalförsamlingar antog 1982 världsaktionsprogrammet för handikappade och ägnade handikappfrågorna ett särskilt årtionde. År 1987 genomfördes en utvärderingskonferens i Stockholm av FN. En av resolutionerna från konferensen uppmanade till att förbereda en konvention om handikappades rättigheter. Den svenska regeringen sökte samarbete med ett antal andra länder för att driva frågan om en konvention, dock utan att lyckas. Istället fick FN:s ekonomiska och sociala råd och den sociala utvecklingskommissionen i uppdrag att tillsätta en arbetsgrupp för att ta fram standard- regler med syfte att tillförsäkra människor med funktionshinder jämlikhet och delaktighet i samhället. Standardreglerna antogs av FN:s generalförsamling hösten 1993. Vid en världskonferens om mänskliga rättigheter år 1993 uttalades att särskild uppmärksamhet borde ägnas att säkra att personer med funktionshinder inte blir diskriminerade och att de tillerkänns lika behandling $i$ fråga om mänskliga fri- och rättigheter i alla delar av samhället.

I ett stort antal länder, t.ex. USA, Australien, Storbritannien och Sydafrika har det under de senaste åren antagits lagar om förbud av diskriminering på grund av funktionshinder. USA är det land som gått längst med the Americans with Disabilities Act (ADA) som antogs år 1990. Lagen omfattar tre huvudområden, nämligen arbetsmarknad, delstater och kommuner samt kommersiell verksamhet. Den bärande principen i lagen är att det är förbjudet att diskriminera någon på grund av funktionshinder. I begreppet diskriminering ingår även otillgänglighet i miljön och i verksamhet, vilket ibland kallas för indirekt diskriminering. ADA ger möjlighet för enskilda personer att stämma företag och myndigheter för diskriminering. När ett ärende om diskriminering till följd av otillgänglighet behandlas, tas hänsyn till hur stora kostnaderna för anpassningsåtgärderna är i förhållande till huvudmännens ekonomiska styrka och storlek. Kraven på att göra verksamheten tillgänglig är därför större för stora företag än för mindre. Lagstiftningen anses ha varit framgångsrik för att förbättra tillgängligheten i synnerhet för personer med rörelsehinder. Andra grupper har inte påverkats i lika hög grad. 
Standardreglerna är 22 till antalet och uttrycker tydliga principiellaståndpunkter i fråga om rättigheter, möjligheter och ansvar på olika samhällsområden. Tanken bakom dem är bl.a. att länderna på olika sätt skall ta ansvar för att reglerna tillämpas och arbeta för principerna om full delaktighet och jämlikhet.

Reglerna kan sägas vara av tre skilda slag. De första fyra anger viktiga förutsättningar som krävs för att uppnå delaktighet. De därpå följande åtta reglerna lyfter fram viktiga huvudområden för delaktighet. De tio sista reglerna beskriver redskap som kan användas för genomförandet och hur reglerna kan omsättas i praktisk handling. Till standardreglerna har kopplats ett system för övervakning och uppföljning. Övervakningsarbetet leds av en särskild rapportör som är utsedd av FN och som till sin hjälp har en expertpanel vars medlemmar i stor utsträckning hämtas från de internationella handikapporganisationerna. ${ }^{1}$

FN:s standardregler har spelat en mycket stor roll både när det gäller att föra upp handikappfrågorna på den politiska agendan i olika länder, men också som medel för att utveckla vissa minimistandards på handikappolitikens olika områden. Så har också varit fallet i Sverige. Handikappombudsmannen har t.ex. använt FN:s standardregler som utgångspunkt vid de uppföljande enkäter om tillgänglighet m.m. som man riktat till landets kommuner. Dessa tar i sin tur oftast utgångspunkt i reglerna för sina egna handikapplaner.

Under senare år har FN:s särskilde rap-

1 Den särskilde rapportören är f.d. statsrådet Bengt Lindqvist. portör i olika avseenden fört fram handikappfrågorna som en del av komplexet mänskliga rättigheter. Förenta Nationernas deklaration om de mänskliga rättigheterna, utgör grunden för tre olika internationella konventioner nämligen a) konvention om avskaffande av alla former av rasdiskriminering, b) konvention om ekonomiska, sociala och kulturella rättigheter och c) konvention om medborgerliga och politiska rätttigheter. För personer med funktionshinder gäller självklart också dessa. Emellertid kan de inte realiseras i praktiken med mindre än att det finns ambitioner hos nationerna att skapa förutsättningar för att de skall kunna utöva sina medborgerliga rättigheter bl.a. genom att delta aktivt inom politiken på olika nivåer.

Under senareår har det inom forskarsamhället förekommit en ganska omfattande diskurs kring handikappbegreppet. Bakgrunden är bl.a. de internationella harmoniseringssträvanden som funnits inom Världshälsoorganisationen (WHO). Som en följd av klassificering av olika sjukdomar ville man också skapa en klassificering av funktionshinder. När man därför publicerade, International Classification of Impairment, Disability and Handicap, ICIDH(WHO, 1980) ville man beskriva konsekvenser som skador och kroniska sjukdomstillstånd får i form av bl.a. handikapp. Det var också ett försök att implementera ett miljörelaterat handikappbegrepp, som tidigare bl.a. slagit rot i Skandinavien.

I WHO:s klassifikation impliceras en kausal kedja från skada till handikapp via funktionshinder. Kausaliteten i resonemangen har bl.a. kritiserats av Nordenfelt (1983). Andra, bl.a. Söder (1983), har anfört

Stig Larsson: Från patient till medborgare 
att WHO:s handikappbegrepp varit allt för individcentrerat. Inte minst under trycket från den internationella handikapprörelsen har WHO under senare år arbetet med en revidering av sin klassifikation. En ny sådan antogs i år (WHO, 2001).

Relationen mellan sjukdom och funktionshinder har många dimensioner. En sådan är tidsutdräkten. Är den som har brutit ett ben och till följd därav har svårt att röra sig handikappad? Svaret måste bli: ja, under den tid som han eller hon upplever handikapp i möte med omvärlden. En annan central fråga är vad som är skada eller sjukdom? Sedan länge har psykiatriska kroniska sjukdomstillstånd ansetts föranleda funktionshinder. Personer med olika typer av psykiatriska diagnoser som organiserar sig anser sig tillhöra gruppen personer med funktionshinder och är också accepterade inom den internationella handikapprörelsen. Här är emellertid också tydliga indefinieringsproblem. Kring beroendesjukdomarna - t.ex. alkoholism - har det förts en livaktig diskurs om dessa rör sjukdomstillstånd (som jag sammanfattat med svenska förtecken i Larsson \& Helleday, 1992). Förenklat uttryckt finns här dels företrädare för ett snävt biologiskt reduktionistiskt synsätt (t.ex. Szasz,1978), vilka hävdar att sjukdomar endast skall definieras på biologisk grund. Detta kontrasterar bjärt mot den sociologiska traditionen, som ser sjukdomsbegreppet i en samhällelig kontext. Banbrytande inom denna var Mausse, som (1924) på basis av ett omfattande etnografiskt material visade att i skilda kulturer ges olika beteenden, som kan leda till insjuknande och död, skilda etiketter. Enkelt uttryckt kan vi antingen ge ett beteende som alko- holberoende epitet som "sjukdom", "asocialitet» eller »kriminalitet». Ur klassificeringssynpunkt - såväl internationellt genom WHO:s sjukdomsklassificering, svensk lagstiftning, behandlingspraxis och i subjektiva upplevelser manifesterade i organiseringen av självhjälpsgrupper - hävdas att alkoholism är en kronisk sjukdom. Frågan är om den också förorsakar funktionshinder och handikapp. Kring denna har det endast lämnats något begränsade teoretiska bidrag (t.ex. Andersson, 1987). Livet som alkoholist - även om man har varit nykter i åtskilliga år - är i vissa situationer handikappande. Subjektiva upplevelser av tillkortakommanden och utanförskap är i grunden de samma som för andra personer med funktionshinder. Det enda konsekventa rimliga sättet att se på beroendesjukdomarna är alltså att de liksom andra psykiska sjukdomstillstånd i sin förlängning i allmänhet innebär funktionshinder och handikapp.

Den nya klassifikationen, ICF, International Classification of Functioning, Disability and Health (WHO 2001), försöker bygga in begrepp på såväl organ-, individ-, och samhällsnivå, men också att inkludera faktorer som berör omgivningen och intra-individuella relationer. I den nya klassifikationen har man sökt förena medicinska och sociala synsätt på handikapp i vad som kallas en »biopsykosocial» modell. Varje aspekt beskrivs med avseende på samspelet mellan det som betraktas som individens inneboendekaraktäristika och hennes sociala och fysiska omgivning. ICF betonar delaktighet och försöker visa komplexiteten i samspelet mellan olika perspektiv på funktionshinder.

I WHO:s nya modell har, som framgår av figur 1, det komplexa och ömsesidiga 


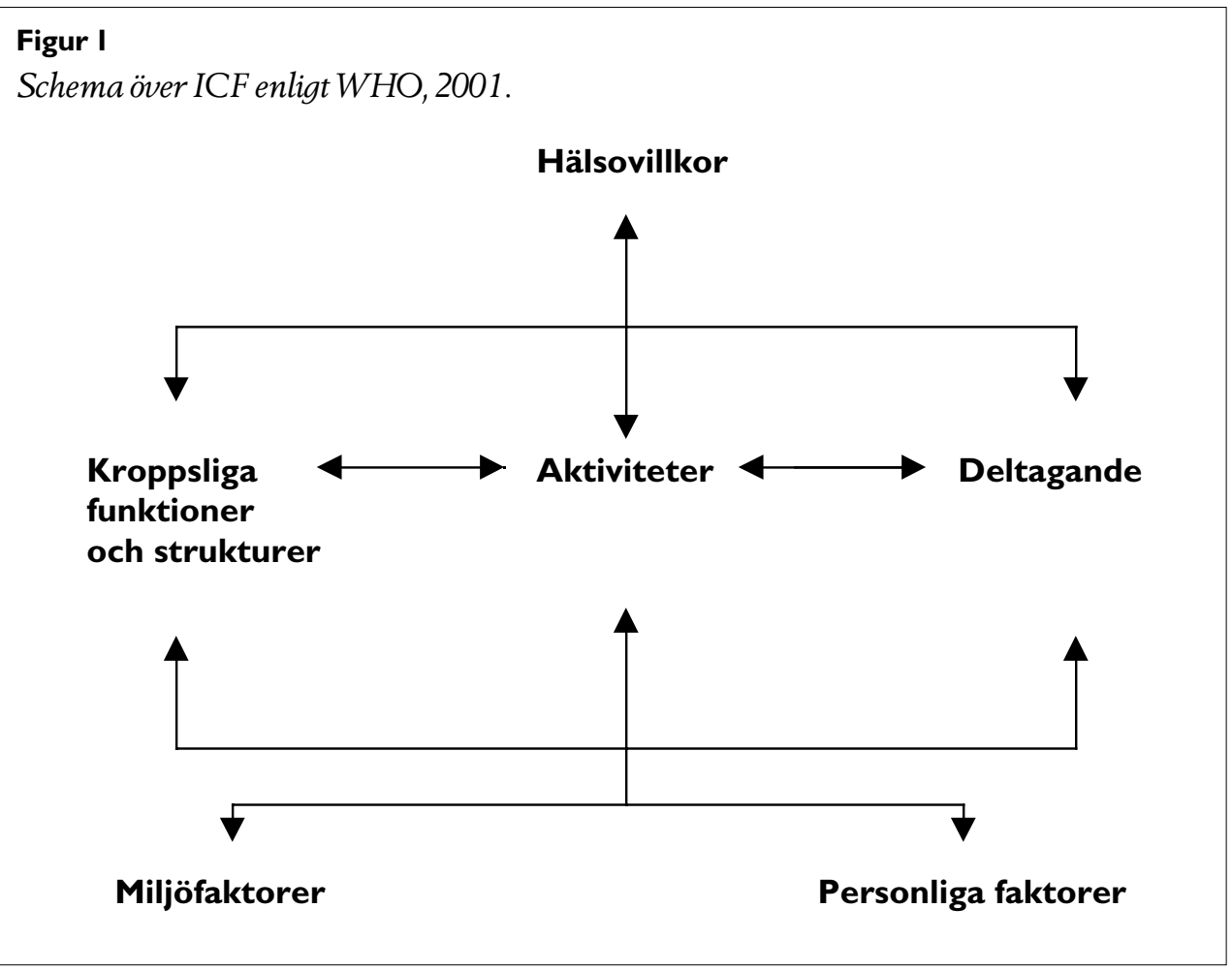

i relationerna mellan de olika faktorerna, som modellen beskriver åskådliggjorts. Det är den mänskliga aktiviteten som är centrerad, men förståelsen av handikappet kan ske både från exempelvis kroppsfunktion, hälsoförhållanden, delaktighet, miljörelaterade eller personliga faktorer (Figur 1).

Inom den engelskahandikappforskningen har det man kallat "den sociala modellen « för funktionshinder ofta lyfts fram. Avsikten har varit att röja undan det snäva individinriktade medicinska sättet att se på funktionshinder och handikapp. ISverige formulerades som ovan nämnts det miljörelaterade handikappbegreppet tidigare, vilket i de flesta avseenden överensstämmer med intentionerna i den sociala modellen. Det torde inte råda någon tvekan om att Skandi- navien i socialpolitiska avseenden under de senaste decennierna varit långt mer utvecklat än Storbritannien på områdena som gäller service och tillgänglighet för personer med funktionshinder. Sannolikt har den svenska kritiken av en snäv medicinsk handikappmodell också påverkat den vetenskapliga diskursen och politiska debatten om funktionshinder på de brittiska öarna.

En av de mest aktiva forskarna vid utformningen av den sociala modellen var Mike Oliver (1983), som senare betonat vikten av att utveckla en social teori kring funktionshinder. Han skisserar en väg, där den sociala handikappteorin bryter med synsättet påfunktionshinder som en personlig tragedi på tre nivåer, nämligen: Den ontologiska, dvs. vilket är handikappets natur?,

Stig Larsson: Från patient till medborgare 
den epistemologiska, d.v.s. vad orsakar handikapp? och den erfarenhetsmässiga, dvs. hur upplevs handikapp? (Oliver, 1996).

Frågan är emellertid om man överhuvudtaget kan tala om ett handikappbegrepp eller en modell eller en social teori om handikapp. I själva verket förekommer en rad olika begrepp och definitioner av funktionshinder parallellt inom olika vetenskapsområden, nationella sfärer och skilda regelsystem. Samtidigt framstår det som uppenbart att gränsdragningen mellan skilda vetenskapsområden luckras upp. Gamla disciplin- ochämnesgränser överskrids därför att de i viktiga avseenden är överspelade. Det finns kanske få sociala forskningsfält där det framstår som så tydligt som på handikappområdet.

Under senare år har flera handikappforskare med feministiska förtecken hävdat att man måste inse att det ökande sambandet i västvärlden mellan kroppsuppfattning och jagidentitet har särskilt negativa konsekvenser för personer med funktionshinder. Tanken på att personer med svåra fysiska funktionshinder exempelvis har sexuellt umgänge, uppfattas ofta som motbjudande och komiskt (Begum, 1992:78). Feministiska handikappforskare har också kritiserat företrädare för den sociala modellen för att förneka upplevelsen av kroppen genom att hävda att fysiska olikheter och begränsningar enbart är socialt skapade (Morris, 1991). Samma typ av reflektioner finns inom det forskningsområde som ägnar sig åt kroniska sjukdomar och funktionshinder (t.ex. Bury, 1997 eller Williams, 1996).

Personer med funktionshinder kan som andra människor tillhöra olika typer av socialt mer eller mindre tydligt förtryckta eller marginaliserade grupper. Ibland har man talat om "dubbelt förtryck" eller "dubbel diskrimineringw. Emellertid har det riktats kritik mot denna terminologi, eftersom man ansett att den implicerar någon form av hierarki mellan olika marginaliseringsstrukturer, då de i själva verket samverkar (Hill, 1994). Istället har begreppet simultant förtryck(Stuart, 1992) vunnit terräng.

\section{Hur många har funktionshinder?}

Beroende på hur man definierar personer med funktionsnedsättningar kommer andelen av befolkningen, som tillhör gruppen att variera väsentligt. Förekomsten av funktionsnedsättningar skiftar starkt mellan olika åldersgrupper. Bland dem som är 80+ är sålunda funktionshinder snarare regel än undantag. I de flesta försök att uppskatta andelen personer med funktionshinder i befolkningen sker det ofta en sammanblandning av sjukdomstillstånd, funktionsnedsättningar och handikapp. I det senaste försöket att göra en mera översiktlig framställning om situationen för personer med funktionshinder,som gjordesinom ramen för det s.k. välfärdsbokslutet (SOU 2001:56), skedde i viss mån detta. Fördelningen enligt denna framgår av tabell 1.

Den undersökning, som kanske bäst åskådliggör förekomsten av funktionshinder hos befolkningen, är den som initierats som en tilläggsundersökning till arbetskraftsundersökningen (AKU). Den första studien av detta slag genomfördes av Statistiska Centralbyrån på uppdrag av AMS och med stöd från dåvarande Rådet för Arbetslivsforsk- 


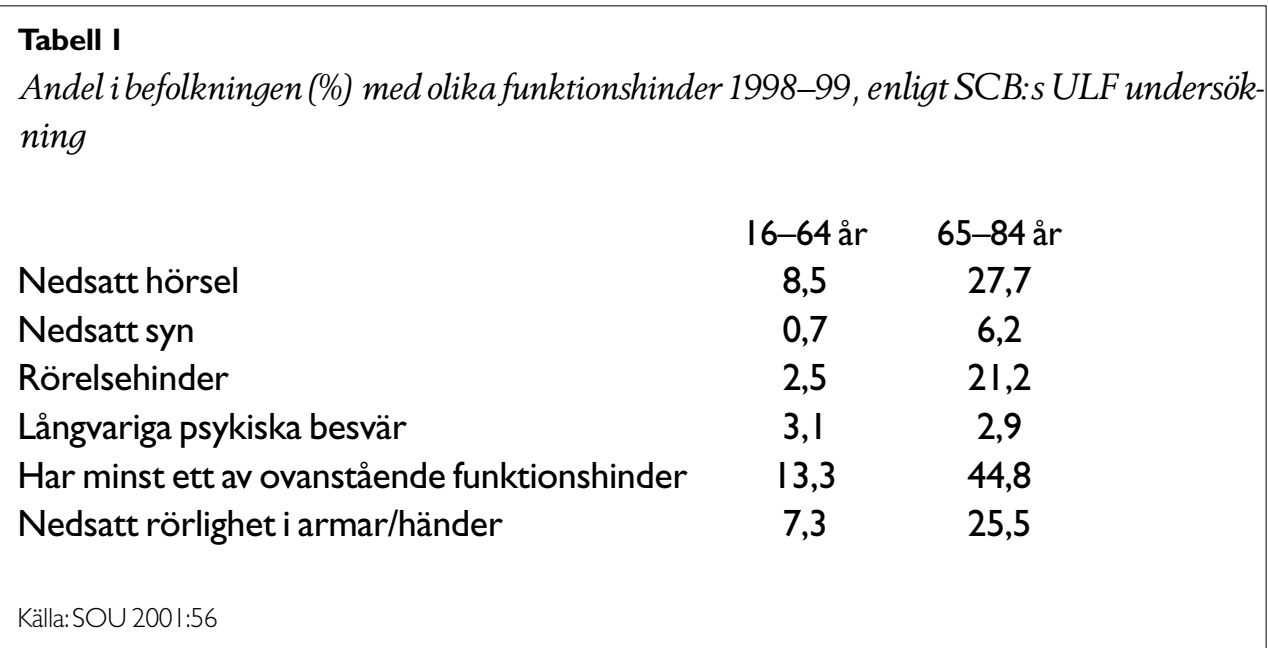

ning och i samarbete med Handikappombudsmannen (SCB 1997). Undersökning har senare också genomförts fjärde kvartalen 1998 och 2000 (SCB, 1999 och 2001). De huvudsakliga resultaten redovisas i figur 2 .
Som framgår av figur 2 har 21,4 procent av Sveriges befolkning i arbetsför ålder uppgivit att de har någon form av funktionshinder. Man har själv fått svara på frågan „Tillhör Du gruppen som har en funktions-

Figur 2

Andel med funktionsnedsättning i den arbetsföra befolkningen (16-64 år).

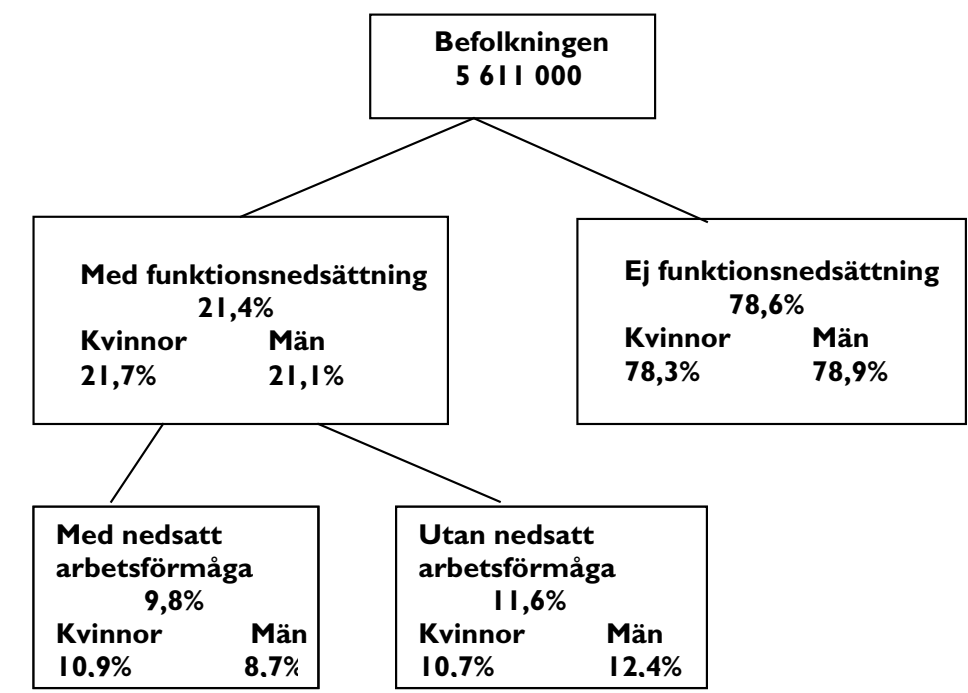

Efter SCB 200I.

Stig Larsson: Från patient till medborgare 
nedsättning?« efter att ha konfronterats med följande definition: „Med funktionsnedsättning menas här att man har nedsatt syn eller hörsel, har tal eller röstproblem, rörelsehinder, allergi eller någon form psykisk funktionsnedsättning. Det kan också vara att man har diabetes, hjärt-lungproblem, mag-tarmsjukdom, psoriasis, epilepsi, dyslexi eller något liknande» (SCB, 2001:66). Jag har själv i andra sammanhang fört fram en metodologisk kritik av undersökningens design (Larsson, 2000), som gör det troligt att andelen personer medfunktionshinderär högre än vad som framgår av den. Benägenheten att i en intervjuundersökning medge att man har ett funktionshinder reflekterar kanske i första hand det samhälleliga och mediala klimatet för handikappade. Idag torde det inte råda någon tvekan om att 20-25 procent av befolkningen i yrkesverksam ålder för närvarande upplever att man har någon form av fysisk eller psykisk betingad funktionsnedsättning. Fördelningen mellan könen är ungefär densamma som för totalbefolkningen. Däremot skiljer sig vissa typer av funktionsnedsättningar mellan könen.

Som framgår av tabell 2 är det en större andel kvinnor än män som har rörelsehinder eller astma/allergi eller annan överkänslighet. Samtidigt är det en större andel män än kvinnor, som har hörselskada, hjärt-kärlsjukdom, diabetes eller lungsjukdom. Det framgår också av tabellen att var tjugonde

\section{Tabell 2}

Män och kvinnor med funktionsnedsättning i befolkningen fördelade efter typ av funktionsnedsättning, år 2000. Procent.

Tabellen läses uppifrån och ned, med utgångspunkt från kvinnor och män

\section{Funktionsnedsättning}

Astma/allergi eller annan Överkänslighet

Diabetes

Dyslexi

Dövhet

Epilepsi

Hjärt-kärlsjukdom

Hörselskada

Mag-/tarmsjukdom

Lungsjukdom

Psoriasis

Psykiskt funktionsnedsättning

Psykisk utvecklingsstörning

Rörelsehinder

Stamning, språk-, tal- eller röststörning

Synnedsättning/blindhet

Annan

\section{Män Kvinnor Samtliga}

$\begin{array}{lll}4,5 & 5,7 & 5,1 \\ 1,6 & 1,1 & 1,3 \\ 0,6 & 0,4 & 0,5 \\ 0,6 & 0,4 & 0,5 \\ 0,2 & 0,2 & 0,2 \\ 1,6 & 0,8 & 1,2 \\ 2,7 & 1,4 & 2,0 \\ 0,8 & 1,1 & 1,0 \\ 0,3 & 0,1 & 0,2 \\ 0,8 & 0,9 & 0,8 \\ 0,8 & 0,9 & 0,8 \\ 0,1 & 0,1 & 0,1 \\ 5,5 & 6,8 & 6,2 \\ 0,2 & 0,1 & 0,1 \\ 2,6 & 2,6 & 2,6 \\ 1,7 & 2,5 & 2,1\end{array}$

Källa:SCB 200 I:3 
person i arbetsför ålder (5,1 procent) lider av astma/allergi eller annan överkänslighet. Både i den senaste och i tidigare undersökningar bekräftas att rörelsehinder är den vanligaste typen av funktionsnedsättning, $\mathrm{i}$ den arbetsföra befolkningen.

Av figur 2 framgår att av de som ansett att man har funktionsnedsättning har knappt hälften nedsatt arbetsförmåga enligt sin egen bedömning, vilket utgjorde 9,8 procent av hela den arbetsföra befolkningen. Enligt denna uppskattning skulle ca 550000 personer i arbetsför ålder ha en nedsatt arbetsförmåga till följd av funktionsnedsättningar. Det finns emellertid andra data som indikerar storleken på denna grupp. Förtidspensionärer har per definitionen nedsatt arbetsförmåga och de utgjorde ca 438000 i december 2000. Till detta kommer gruppen långtidssjukskrivna. Vid motsvarande tidpunkt fanns 239672 sjukfall som översteg 30 dagar. Antalet förtidspensioner och långtidssjukskrivningar överstiger sålunda väsentligt den siffra, som SCB får fram. Dessutom tillkommer även andra grupper, som per definition har nedsatt arbetsförmåga, nämligen personer med warbetshandikapp " ( som är ett något märkligt och föga precist begrepp, som används inom AMS, se Larsson,1996). Inom Samhall arbetade även ca 25000 personer med s.k. arbetshandikapp, och det fanns samtidigt omkring 50000 med lönebidrag (av dessa kan en mindre del ha varit långtidssjukskrivna eller haft partiell förtidspensionering/ sjukbidrag). Dessutom fanns det ett antal "arbetshandikappade" i andra typer av arbetsmarknadspolitiskaåtgärder,som ejvar sjukskrivna eller pensionerade under denna tid. Personer med nedsatt arbetsförmåga i arbetsför ålder validerade genom jämförelser med offentlig statistik ger sålunda en högre siffra, kanske snarare 15 procent. Orsaken till diskrepansen kan troligen i hög grad sökas i att personer med psykiskt relaterade funktionshinder känner sig skambelagda och därför inte anger sig tillhöra gruppen handikappade.

Förekomsten av funktionsnedsättningar i befolkningen varierar också mellan olika delar av landet. Sålunda fann SCB att andelen personer med funktionsnedsättningar i Stockholms län var lägst med 18 procent. Motsvarande siffra för norra Sverige var 24 procent. Jämför man med internationella studier finns också stora skillnader mellan t.ex. de olika staterna i USA. Här har man i flera undersökningar använt ett handikappbegrepp liknande det, som SCB använder sig av för gruppen som har nedsatt arbetsförmåga. Burkhauser et. al. (2001) har jämfört hur prevalensen självrapporteradefunktionsnedsättningar varierar mellan olika undersökningar beroende på bl.a. tidpunkt, definitioner och metodik. De fann att förekomsten av funktionsnedsättningar varierade mellan 21,5 till 25 procent åren 1983-96. Vid studier av nedsatt arbetsförmåga kommer man fram till en variationsgrad mellan 9,8 och 11 procent. Med andra definitioner blir siffrorna både högre och lägre. Emellertid landar man ungefär på samma nivåer som SCB:s undersökningar i Sverige i de arbetsföra åldrarna. I USA har man emellertid haft en ännu snävare åldersdefinition, nämligen 25-61 år.

Med hänsyn till den accelererande ökningen av funktionshinder i åldrarna över 65 utgör sannolikt andelen personer med funktionshinder av hela Sveriges vuxna 
befolkning minst en tredjedel. För att förstå funktionshinder och handikapp både ur individuella och samhälleliga perspektiv, är det viktigt att i varje fall slå fast att det är en mycket stor del av befolkningen som är berörd.

\section{Handikappforskning $i$ utveckling}

Under senareår har uppmärksamheten kring handikappforskningen utvecklats påtagligt. Man kan kanske i första hand härleda det ökade intresset till två källor. Den första har samma flöde som t.ex. genusvetenskap eller etnicitetsforskning. Personer med funktionshinder tillhör liksom kvinnor och invandrare en mer eller mindre klart urskiljbar samhällelig grupp, som i olika avseenden känner sig ekonomiskt och socialt eftersatt. Dessa upplevelser har man fått bekräftade av forskarsamhället men också av statsapparaten, bl.a. genom ombudsmannainstitutioner eller antidiskrimineringslagstiftning. Den andra källan är det ökade intresset för forskning bland de yrkesgrupper, som främst arbetat med personer med funktionsnedsättningar. Genom strävan efter kunskapsbaserad professionsutveckling har t.ex. arbetsterapeuter, logopeder, sjukgymnaster, sjuksköterskor eller socionomer under de senaste decennierna fått sina utbildningar integrerade i universitetsvärlden i många länder.

Det är bl.a. mot denna bakgrund och statsmakternas aktualisering av forskningsfältet som man skall förstå att dåvarande Socialvetenskapliga forskningsrådet (SFR) 1999 beslöt att genomföra en utvärdering av den svenska handikappforskningen. Det var inte bara den av SFR finansierade forskningen som avsågs, utan också den som fått stöd från andra forskningsråd. Fyra professorer med delvis skilda ämnesinriktningar erhöll uppdraget att genomföra utvärderingen. De var Gary L. Albrecht från University of Illinois at Chicago, Alan M. Jette från Boston University, Helen Petrie från University of Hertfordshire och Linda Siegel från University of British Colombia. Eftersom det nya Forskningsrådet för Arbetsliv och Socialvetenskap (FAS) fått ansvaret för handikappforskningen, finns det anledning att i det här sammanhanget koncentrerat återge en del av den internationella utvärderargruppens försök att sammanfatta den svenska handikappforskningen (Albrecht et.al., 2001). I den sammanställning som görs i utvärderingen framgår att antalet forskare som man lyckades identifiera och definiera var totalt 139. Totalt svarade dessa för 170 olika projekt. Fördelningen på olika ämnesområden såsom man klassificerade dem framgår av tabell 3. Det kan noteras en kraftig dominans av ämnena pedagogik och psykologi. En tredjedel av alla forskare som finns i förteckningen är verksamma inom dessa discipliner. Över 60 procent av forskarna räknar sig i första hand som samhällsvetare. ${ }^{2}$

Som i alla inventeringar av forskning är det mycket troligt att man inte nått samtliga i målgruppen och att dessutom de som nåtts av olika skäl inte alltid medverkat med uppgifter. Sålunda ingår i sammanställningen endast 22 av 33 forskare (66 procent) som erhållit anslag från dåvarande Socialve-

2 I sammanställningen var man något oegentlig genom att inte räkna socialt arbete till samhällsvetenskaperna. Det har jag gjort i min summering. 


\section{Tabell 3}

Sammanställning av projekt och forskare inom handikappområdet $i$ Sverige $i$ början av 2000.

\section{Forskningsområde}

Pedagogik

Psykologi

Sociologi

Andra samhällsvetenskaper

Teknologi

Medicin

Hälsovårdsvetenskaper

Lingvistik

Socialt Arbete

Totalt

\begin{tabular}{cccc}
\multicolumn{2}{c}{ Projekt } & \multicolumn{2}{c}{ Forskare } \\
Antal & $\%$ & Antal & $\%$ \\
29 & 17 & 19 & 14 \\
27 & 16 & 22 & 16 \\
25 & 15 & 17 & 12 \\
21 & 12 & 19 & 14 \\
18 & 11 & 18 & 13 \\
15 & 9 & 15 & 11 \\
14 & 8 & 14 & 10 \\
11 & 6 & 5 & 3 \\
10 & 6 & 10 & 7 \\
170 & 100 & 139 & 100
\end{tabular}

Källa:Albrecht et.al 200 I

tenskapliga Forskningsrådet för handikappforskning för perioden 1995-2000. Frågan är varför många forskare som varit verksamma inom handikappområdetändock inte valt att definiera sig själva som handikappforskare.

De flesta forskare som arbetar med sjukdomars etiologi, utveckling och behandling, även om de $\mathrm{i}$ allmänhet förorsakar svåra funktionshinder, anser sigknappast som handikappforskare. Dessa exkluderades också i sammanställningen för utvärderingen, där detta explicit framhöllsi uppropet för inventeringen. Om studierna avsåg att undersöka möjligheter att leva ett oberoende liv skulle de dock inkluderas (Albrecht et. al. 2001:35). Det är därför rimligt att anta, att många forskare inom medicin, särskilt de med fokusering på habilitering eller rehabilitering, från tid till annan lämnar viktiga vetenskapliga bidrag till handikappforskningen. Områden som neurologi, oftalmologi, ortopedi, psykiatri eller reumatologi fokuserar dock i första hand på skador eller sjukdomar, deras förlopp och behandling, medan habilitering och rehabilitering ofta has omhand av andra medicinska professioner än läkare, t.ex. arbetsterapeuter, sjukgymnaster eller synpedagoger.

Bl.a. mot bakgrund av den nationella handlingsplanen för handikappolitik erhöll FAS i uppgift att i samråd med övriga berörda forskningsfinansiärer utarbeta ett program för forskning om funktionshinder och handikapp på uppdrag av regeringen. En särskild kommitté utsågs och denna kunde presentera förslaget till handikappforskningsprogrammet under hösten (FAS, 2001). Till grund för kommitténs arbete har bl.a. legat den internationella utvärderingen, men också en del tidigare översikter (t.ex. Hjelmquist et.al. 1994 och Backenroth-Osahko et.al. 1996). I programmet har man använt följandeavgränsning av forskning om funktionshinder och handikapp: „Forskningen om funktionshinder och handikapp 
kan vara samhälls-/beteendevetenskaplig, humanistisk, teknisk/naturvetenskapligeller medicinsk/vårdvetenskaplig. Forskningen kan avse individ-, grupp- eller samhällsnivå. Centralt är att forskningen har ett miljörelativt perspektiv. Denna forskning är till sin karaktär ofta tvär- och/eller mångvetenskaplig. Hur det miljörelativa perspektivet gestaltas varierar dock från ett område till ett annat" (FAS 2001:8). Formuleringen är inte särskilt klar, utan tvärtom motsägelsefull, särskilt med hänsyn till den metavetenskapliga diskurs, som förs inom skilda discipliner samtidigt som den tycks utgå från en något oreflekterad hierarki uppdelad på skilda nivåer från individ till samhälle. I redogörelsen för forskningen utgår man i princip från fakultetsområden dvs. 1 . naturvetenskapligt/tekniskt, 2. medicinskt/ vårdvetenskapligt,3. samhällsvetenskapligt/ humanistiskt, 4. beteendevetenskapligt perspektiv.

Det ligger i sakens natur att utvärderingseller programkommittéer som arbetar under kortare tid, inte kan göra någon djupare eller mera sammansatt analys av forskningsläget inom ett så vidsträckt fält som handikappforskningens. Det betyder inte utan att de bidrag de lämnat i flera avseenden varit värdefulla. Programgruppen konstaterar sålunda att ett genomgående tema för området är tvärvetenskapligheten. Denna har präglat handikappforskning under en lång följd av år och innebär både en styrka och svaghet. I inomvetenskapligt perspektiv innebär detta potentiellt nyskapande genom gränsöverskridningar, samtidigt som området kan löpa risk för att uttunnas och bli i avsaknad av fokus (FAS, 2001).

Frågan om handikappforskning skall bedrivas i etablerade discipliner eller inom ett särskilt ämnesområde, som exempelvis betecknashandikappvetenskap,somär fallet vid den gemensamma satsningen man gör vid universiteten i Linköping och Örebro, har ibland diskuterats tämligen intensivt. I den anglosaxiska världen har ämnet Disability Studies blivit ett etablerat forskningsområde, som på vissa universitet är en självständig disciplin, på andra delvis som delar av ett curriculum inom samhällsvetenskapliga ämnen som sociologi, socialt arbete, socialpolitik, pedagogik, psykologi eller inom medicinska områden som samhällsmedicin, folkhälsovetenskap, omvårdnadsvetenskap eller arbetsterapi. Women Studies såväl som Disabiliy Studies har fokuserat bristande jämlikhet, utanförskap, brist på delaktighet och orättvisor, men också hinder och möjligheter att nå full och lika delaktighet. I företalet till den mest omfattande (och nyaste) grundboken i Disability Studies heter det: "The ideas for this handbookgerminated in the American civil rights moment of the 1960:s and took root in the international human rights impetus of the past 25 years» (Albrecht, Seelman, Bury 2001:ix). Samma formulering skulle egentligen kunna gälla för en grundbok i kvinnovetenskap.

Frågan om handikappvetenskap skall vara en egen disciplin eller inte är snarare en fråga om akademisk organisering än om vetenskapligt innehåll. Istället för antingen eller tycks det - precis som inom kvinnovetenskapsfältet - finnas behov för både och. Sammanhållen handikappvetenskaplig forskning berikar den som bedrivs om funktionshindrades villkor inom de gängse disciplinerna. På samma sätt kan den forsk- 
ning som sker inom etablerade ämnesområden tillföra handikappvetenskapen mycket i fråga om fördjupade perspektiv och utveckling av metodik.

Inom de olika vetenskapsområdena, som definierar sig genom en befolkningsgrupp artikuleras i varierande grad de inneboende avgränsningsproblemen. Barn och ungdomar blir äldre, invandrare återvandrar, assimileras eller integreras. Kön är i flera avseenden en variabel mer än en dikotomi. Det är mycket få som legalt byter kön under sitt eget livsförlopp, men i ett fler generationsperspektiv sker det i princip hos hälften av de nya biologiska uppenbarelser som våra barn är. Sjukdomar och skador, som förorsakar handikapp kan man ha i varierande grad och art under livet, relaterat till den medicinska skada eller sjukdom som man lider av, men också i relation till olika sociala och fysiska miljöer. Svårigheterna att definierahandikappforskningen är något den har gemensamt med många vetenskapsområden, både med och utan befolkningsgruppsprefix.

Hos de förra finns dock ett ofta närvarande, men sällan artikulerat krav på att företrädare för gruppen också skall var representerade som aktiva forskare inom området. Inom t.ex. kvinnovetenskap är en överväldigande majoritet av de aktiva forskarna kvinnor. Det finns idag få personer medallvarligafunktionshinder,somäraktiva som forskare och ännu färre inom handikappområdet. I FN:s standardregler (1996) krävs att också forskare med egna funktionshinder rekryteras till handikappforskningen. Forskningsområden, som definierar sig genom befolkningsgrupper innehåller element av vad som ibland benämns empo- wermentstrategier. Inom kvinnoforskningen gör exempelvis Cook och Fonow (1986) detta när man utvecklar principer för feministisk vetenskaplig metodologi. Inom den kvinnovetenskapliga diskursen (t.ex. FossFridlizius, 1990) ges inte sällan olika kunskapsteoretiska argument för att vetenskapliga anspråk kan förenas med anspråk på delaktighet och ökad makt.

Att det reses krav från kvinnor att få delta i kvinnoforskning, samer att få engagera sig i forskning kring samernas förhållande eller funktionshindrade att bedriva handikappforskning är legitimt ur många - inte minst inomvetenskapliga - perspektiv. Att leva med allvarligt funktionshinder innebär ackumulering av kontinuerliga erfarenheter i mötet med det samhälle, som i huvudsak är skapade för andras förutsättningar.

Både inom kvinno-, invandrar-och handikappforskningen har "mångfald" lyfts fram som ett viktigt begrepp för delaktighet på olika arenor. Bakom detta finns ambitionen att inkludera grupper $-t$. ex. invandrare eller funktionshindrade som ofta är marginaliserade, i olika samhälleliga avseenden (Cox 1993; Wilson 1996). Att säkerställa mångfalden både inom den privata och offentliga sektorn, framhålls som viktigt ur inte minst legitimitets- och normbildningssynpunkt. Inom den internationella jämställdhetspolitiken - inte bara på handikappområdet- används ofta också begreppet mainstreamingför att tydliggöra allas ansvar och minsta möjliga antal särlösningar. Enkelt uttryckt innebär detta att så långt möjligt skall all verksamhet i samhället ta sikte på att också möjliggöra för funktionshindrade att ha full delaktighet.

Stig Larsson: Från patient till medborgare 
Principen om mainstreaming, har också anammats på den europeiska nivån. European Disability Forum (EDF) har därvid kommit att spela en viktig roll för att inplantera principen på olika politikområden inom Europeiska unionen. På samma sätt kan man säga att de länder som har antagit en antidiskrimineringslagstiftning liknande ADA i USA också har anslutit sig till mainstreamingmodellen.

Den internationella utvärderingsgruppen (Albrecht et. al. 2001) kommer med nio olika rekommendationer beträffande svensk handikappforskning. De allra flesta av dessa har karaktären av förstärkningar av infrastrukturen för forskningsområdet. Uppenbart har också gruppen funnit att det finns olika riktningar företrädda inom den svenska handikappforskningen och man tycker att det är viktigt att uppamma en dialog mellan sociala konstruktionister och positivister liksom mellan forskare med kvalitativ eller kvantitativ metodologiskt perspektiv, men också mellan forskare och "policymakers" (Albrecht et. al. 2001:7). ${ }^{3}$ Den kommitté, som arbetat med ett program för handikappforskningen, inriktade sig i första hand på att ange finansiella ramar för olika insatser. Man kunde också iaktta de många skilda ingångarna till handikappforskningen. De präglas bl.a. av vad man kallar verksamhetsnära versus social praxisinriktad forskning (FAS, 2001). Frågan är dock om inte det finns en gemensam ingång till handikapp-

3 Det NNDR-arrangemang som artikelförfattaren var ansvarig för och som delvis är grunden för föreliggande temanummer omnämns av gruppen som ett exempel på hur dessa dialoger kan föras. forskningen, där principerna om mångfald, mainstreaming, full delaktighet och medborgerliga rättigheter fokuseras.

\section{Handikappvetenskap i ett nytt paradigm?}

Thomas Kuhn (1979) benämnde det mönster som styr vetenskapligt tänkande som paradigm. Han menade att liksom lingvistiska böjningsmönster utgår vetenskaper från bestämda förebilder. Enligt Kuhn definieras paradigm som ett vetenskapligt arbete som för en viss tid ger upphov till en särskild forskningstradition som mer eller mindre tydligt anger vilka teorier, metoder och observationer som är relevanta och vad som ska förstås som god vetenskap. Det som bestämmer vetenskapens förändring är enligt Kuhn bl.a. inom forskarsamhället hierarkiska och normativa strukturerna (Brante, 1981).

Det har som bekant gått viss inflation i begreppet paradigm. Den närmast revolutionära förändringen av synen på funktionshindrade som har ägt rum från tiden före andra världskriget till idag är ett fundamentalt perspektivskifte. Emellertid kan inte detta härledas till ett bestämt verk, till en bestämd person eller till ett bestämt vetenskapsområde. I en mening är det artikulerat i FN:s deklaration om de mänskliga rättigheterna. I en annan är den förenad med samma idémässiga innehåll som givit upphov till kvinnovetenskap eller etnicitetsforskning med jämlikhet och rättvisa som normativa förtecken.

Det modernistiska objektifierade handikappbegreppet nådde sin kulmen in absur- 
dum i Nazityskland. Den industriella förintelsen av personer med grava funktionshinder föregick förintelsen av judar. I flera avseenden finns en direkt länk mellan funktionshindrades och judarnas öden under nazitiden (Friedlander, 1995). Mer eller mindre grumliga vetenskapliga föreställningar med rashygien, exklusion och euftanasi gällde både handikappade och "mindervärdiga" raser och var sprungna ur samma slags tankegods. Även om det fanns skillnader i förhållningssätt mellan Nazisttyskland och t.ex. England eller Sverige, fanns det också en gemensam nämnare i medicinsk definiering och social exkludering.

De faktorer, som lett fram till att vi i grunden distanserat oss från detta synsätt på funktionshinder vetenskapligt och politiskt är inte bara en produkt av vetenskaplig och politisk utveckling, utan också en reflex av den allmänna välfärdsutvecklingen. I takt med ökade resurser har vi också haft råd att bry oss om de svagaste. Men det inklusiva perspektivet på personer med funktionshinder har inte kommit mekaniskt av sig självt. Samhälls- och beteendevetenskaperna lämnade flera viktiga bidrag under den tidiga efterkrigstiden genom t.ex. Adorno et.al. (1950) i analysen av den auktoritära personligheten eller Allport (1954) i analysen av fördomarnas natur - för att bara nämna några.

Kuhn talar om inkommensurabilitet. Det innebär att vissa teorier som avser att behandla vad som tycks vara samma ämnesområde eller problem, definiera vissa av sina grundläggande begrepp så skilt från varandra att det knappast kan jämföras utifrån objektiva eller neutrala kriterier. Det finns kanske de som hävdar att en medicinsk kontra en social modell i förståelsen av funktionshinder är inkommensurabla. På samma sätt hävdasstundom oförenligheten $\mathrm{i}$ personnära verksamhetsanknuten teori och den som gäller forskning om t.ex. samhällelig delaktighet. I själva verket handlar det snarare om olika sätt att nalkas kunskapsobjektet, funktionshinder, från skilda grundläggande discipliner. Det finns många försök att förena dessa synsätt av vilka den nya WHO-klassifikationen är ett. Det finns emellertid en oförenlighet mellan de värdesystem som hävdar allas rätt till liv och samhällsgemenskap och de som bygger på föreställningar om att man kan exkludera vissa människor p.g.a. olika biologiska, medicinska eller sociala karakteristiska. Det senare synsättet har inte försvunnit genom fascismens nederlag under andra världskriget. I stället har den haft viss renässans hos de som hävdar djurens (i allmänhet inte bakteriernas) likaberättingande (t.ex. Singer 1996).

Den svenska handikappolitiken tycks ha anammat det nya grundläggande perspektivet, där medborgerliga rättigheter, mångfald, mainstreaming och full delaktighet är ledorden. I de nationella målen för handikappolitiken (prop. 1999/2000:79) framhålls att syftet är att det handikappolitiska arbetet tydligare skall inriktas på att ta bort de hinder som finns för funktionshindrades fulla delaktighet i samhället. De nationella målen formuleras därvid på följande sätt:

En samhällsgemenskap med mångfald som grund.

Att samhället utformas så att människor med funktionshinder i alla åldrar blir fullt delaktiga i samhällslivet. Jämlikhet i levnadsvillkor för flickor och

Stig Larsson: Från patient till medborgare 
pojkar, kvinnor och män med funktionshinder.

Det framhålls vidare: "Ytterst är handikappolitiken en demokratifråga - samhället måste byggas med insikten om att alla människor är lika mycket värda, har samma grundläggande behov och skall behandlas med samma respekt, att mångfald berikar, att varje människa med sin kunskap och erfarenhet är en tillgång för samhället" (prop. 1999/2000:79).

Den handikappforskning som hittills bedrivits i Sverige har i viktiga avseenden bidragit till att sätta fokus på den bristande delaktigheten. Emellertid har kunskapen om personer med funktionshinder ur olika makt- och mångfaldsperspektiv i allt väsentligt lyst med sin frånvaro. Trots att de knappast är mer än marginellt representerade i politiken finns det bara enstaka arbeten kring personer med funktionshinder och demokrati (Larsson, 2001). Till skillnad från t.ex. kvinno- eller invandrarforskningen relateras sålunda sällan handikapperspektiven till maktstrukturer. Internationellt har också en del forskning initierats kring temat handikapp och mänskliga rätttigheter. Bl.a. har frågan om en särskild internationell konvention mot diskriminering av personer med funktionshinder aktualiserats. Det är emellertid uppenbart, att det är långt mellan retoriska målsättningar om full delaktighet och deras omsättning till realiteter. Även om delaktighetsprincipen i kölvattnet av de mänskliga rättigheterna blivit något av ett nytt paradigm för handikappforskningen, har den avsatt få spår på centrala samhällssektorer. I detta avseende befinner sig kanske politiken (och för den delen också forskningen) på samma nivå som gällde för kvinnorna under mellankrigstiden.

Framtidens handikappforskning har kanske därför mer att lära av de vetenskapliga insatser som görs om andra marginaliserade grupper än kring olika diagnosgrupper. Frågan är om mångfaldsperspektivet också leder oss in mot en gemensam inklusionsforskning. Teorierna kring social exklusion är i flera avseenden generella för alla utsatta befolkningsgrupper (Byrne, 1999). Social exklusion skall därvid ses som en process som knyter an till bl.a. C. Wright Mills länkning mellan individer och sociala sammanhang. En annan utgångspunkt tas i processen där privata erfarenheter blir sociala, bl.a. med anknytning till livsvärlden(Schutz, 1970) och över- och underordningsstrukturer. Att etablera den gemensamma vetenskapen om utanförskapet blir kanske handikappforskningens framtida väg tillsammans medbl.a. genus-, etnicitets- eller äldreforskningen.

\section{Litteratur}

Allport, G.(1954): The Nature of Prejudice. Reading, Massachusetts, Addison-Wesley Publishing Company.

Adorno, T.W. (1950): The Authoritarian Personality. New York, Harper.
Albrecht, G., Sellman, K. \& Bury, M. (red) (2001): Handbook of Disability Studies. London, Sage Publications.

Albrecht, G., Jette, A., Petrie,H. \& Siegel,L. (2001): An Evaluation of Swedish Disability Research. 
FAS, Forskningsrådet för Arbetsliv och Socialvetenskap, Stockholm.

Anderson, DJ. (1987): Living with Cronic Illness. Center City, Hasseldon.

Backenroth-Ohsako, G., Hjelmquist, E., Rönnberg, J. \& Wadensjö, E. (1996): Funktionshindrades villkor $i$ arbetslivet. En översikt över forskning och utvecklingsarbete. Rådet för arbetslivsforkning och Socialvetenskapliga forskningsrådet.

Begum, N. (1992): Disabled Women and the Feminist Agenda, i Feminist Review, 40, 70-84.

Brante, T. (1981): Vetenskapens struktur och förändring. Lund, Doxa.

Burkhauser, R., Houtenville, A. \& Wittenburg, D. (2001): Userguide to Currentstatistics on the Employment of People with Disabilities. Presented at the Conference: The Persistence of Low Employment Raids of People with Disabilities course and policy implications, Oktober 2001, Washington DC.

Bury, M. (1997): Health and Illness in a Changing Society. London, Routledge.

Cook, J. \& Fonow, M. (1986): Knowledge and Women's Interests: Issues of Epistemology and Methodology in Feminist Sociological Research, i Sociological Inquiry 56: 2-29.

Cox, T. (1993): Cultural Diversity in Organizations. San Fransisco, Berret-Kohler Publisher.

Daunt, P. (1991): Meeting Disability: A European Response. London, Cassell.

De Jong, G. (1981): The Movement for Independant Living: Origins, Ideology and Implications for Disability Research, i Brechin, A., Liddiard, P. \& Swain, J. (red) Handicap in a Social World. Hodder, Sevenoaks.

Driedger,D. (1989): The last Civil Movement: Disabled Peoples' International. London, Hurst \& Co.

Ekensteen, V. (1996): Från objekt till subjekt i sitt eget liv, i Tideman, M. (red) Perspektiv på funktionshinder och handikapp. Stockholm, Johansson och Skyttmo.

FAS (2001): Program för forskning om funktionshinder och handikapp. Stockholm, FAS.

FN (1986): Standardregler för att tillförsäkra människor med funktionsnedsättning delaktighet och jämlikhet. Stockholm, Utrikesdepartementet \& Socialdepartementet.

Foss-Fridlizius, R. (1990): Relativism och realism i feministisk vetenskapsfilosofi, i Kvinnovetenskaplig tidskrift, no. 3 .

Friedlander, H. (1995): The Origins of Nazi Genocide: From Euthanasia to the Final Solution. Chapel Hill, The University of North Carolina Press.

Hill, M. (1994): They are not our Brothers; The Disability Movement and the Black Disability Movement, I Begum, N., Hill, A. \& Stevens, A. (red) Reflections. London, Central Council for the Education and Training of Social Workers.

Hjelmquist E., Rönnberg J. \& Söder M. (1994): Svensk forskning om handikapp. En översikt med social- och beteeendevetenskapliga perspektiv. Socalvetenskpliga forskningsrådet.

Kuhn, T. (1979): De vetenskapliga revolutionernas struktur, filosofi och vetenskapsteori. Stockholm, Thales.

Larsson, S. (1996): De funktionshindrade och arbetsmarknaden, i Tideman, M. (red) Perspektiv på funktionshinder och handikapp. Stockholm, Johansson \& Skyttmo förlag.

Larsson, S. (2000): Nya fält och former på arbetsmarknaden för personer med funktionshinder. HAREC, Centrum för handikapp- och rehabiliteringsforskning, Lunds Universitet, Malmö.

Larsson, S. (2001): Delaktigheter för Personer med Funktionshinderi detKommunalpolitiska Arbetet, i Att vara med på riktigt - demokratiutveckling i Kommuner och Landsting, bilagor till betänkande av Kommundemokratikommittén, SOU 2001:48.

Larsson, S. \& Helleday, A.(1992): DenSvenskaMinnesotamodellen. Stockholm, Socialstyrelsen.

Lorentsen, O. \& Berge, A. (2000): Evaluering av KK-stiftelsens programområde IT - utbildning ochfunktionshinder/handikapp.Stockholm,KKstiftelsen.

Mausse, M. (1924): Les Techniques des cortes, Paris.

Morris, J. (1991): Pride Against Prejudice. London, Woman's Press.

Nordenfelt (1983): On disabilities and their classif-

Stig Larsson: Från patient till medborgare 
cation: a study in the theory of action inspired by the International Classification of Impairments, Disabilities, and Handicaps(ICIDH). Linköping, Linköpings universitet.

Oliver, M. (1983): SocialWork with Disabled People. London, Macmillan.

Oliver, M. (1992): Changing the Social Relations of Research Production? i Disability, Handicap and Society, 7 (2), 101-14.

Oliver, M. (1996): Defining Impairment and Disability: issus at stake, i Barnes, C. \& Mercer, G. (red) Exploring the Divide. Leeds, The Disability Press.

Qvarsell,R.(1991):Vårdensidéhistoria.Stockholm, Karlssons förlag.

Regeringens proposition 1999/2000:79. Frånpatient till medborgare - en nationell handlingsplan för handikappolitiken.

SCB (1997): De funktionshindrades situation på arbetsmarknaden - en pilotstudie. Stockholm, Statistiska centralbyrån.

SCB(1999): Funktionshindradessituation påarbetsmarknaden - 4:e kvartalet 1998. Stockholm, Statistiska centralbyrån.

SCB (2001): Situationen på arbetsmarknaden för personer medfunktionsnedsättningar-4:ekvartalet 2000. Stockholm, Statistiska centralbyrån.

Schutz, A. (1970): On Phenomenology and Social Relations: selected writings. Chicago, University of Chicago Press.

Singer, P. (1995): Rethinking life \& death: the collapse of our traditonal ethics. London, Oxford University Press.
SOU 1964:43. Social omvairdnadav handikappade. En sammanställning gjord inom Socialpolitiska kommittén. Stockholm.

SOU 1976:20. Kultur åt alla. Betänkande av Handikapputredningen. Stockholm, Liber Förlag.

SOU 1999:21. Lindqvists nia Slutbetänkande från Utredningen om bemötande av personer med funktionshinder. Stockholm, Fakta info direkt.

SOU 1999:73 Handikappombudsmannens framtida förutsättningar och arbetsuppgifter. Betänkande av Utredningen om översyn av Handikappombudsmannen. Stockholm, Fakta info direkt.

SOU 2001:56. Funktionshinder och välfärd. Delbetänkande från Kommittén Välfärdsbokslut.

Stuart, O. (1992): Race and Disability: what type of double disadvantage, i Disability, Handicap and Society, 8(3): 249-264.

Szasz, S. (1978): Psykoterapi - en myt. Stockholm: Alba.

WHO(1980): International classification of impairments, disabilities, and handicaps: a manual of classification relating to the consequences of disease. Geneva, World Health Organization.

WHO (2001) International Classification of Functioning,DisabilityandHealth(ICF). Geneva, World Health Organization.

Williams, S. (1996): The vicissitudes of Embodiment across the Chronic Illness Trajectory $\mathrm{i}$ Body and Society, 2(2): 23-47.

Wilson, T. (1996): Diversity at Work: The Business case for Diversity. Toronto, John Wiley and Sons.

\section{Summary \\ From patient to citizen - persons with functional disabilities meet a new paradigm}

This article is an introduction primarily intended for researchers in the field of social science who are not usually involved in the sphere of disability. It sums up and problematizes certain basic questions. One is: what is disability? There is an extensive conceptual discourse about this, taking some of its nourishment from welfare policy, where there is a need to formulate the rules determining who may be entitled to certain bene- 
fits. At times the discussion of the concept of disability has been affected by manifest oppositions between different disciplines. Another important approach to the concept of disability has been international efforts such as the UN Declaration of Human Rights and the standard rules on disability drawn up in its spirit. The WHO's efforts at harmonization have led to the adoption of a new classification system in 2001.

Another central question is: how many people with functional impairments are there? There are of course statistical sources associated with different definitions, which can give us a knowledge of the extent of different disabilities in the population. In this account I confine myself mainly to Sweden. Here at least a third of the population feel that they are disabled.

The number of people with functional impairments presumably covaries with how far they are accepted as a group by the social climate. It is reasonable to suppose that the most important changes are linked to the general development of welfare. In political terms this mostly means that the most important reforms in social policy which concern people with functional impairments are the general reforms.

A third question concerns the situation of disability research in Sweden. Here I present reports from two groups working in conjunction with the Research Council for Working Life and Social Science. The international discourse in disability research agrees in several important respects with that in Sweden.

Finally, one may ask: what has happened in total in the field of disability? In this section I weave together and summarize the discussion in the first three sections. The conclusion is that, in the last fifty years a new outlook or - if you will - a new paradigm has been shaped as a basis for the view of people with functional impairments, but this is only reflected to a limited extent in research. 